\title{
小児期・青年期の慢性心不全緩和ケアの現状と課題
}

\author{
森 雅啓, 青木 寿明, 藤﨑 拓也, 橋本 和久, 松尾 久実代, \\ 浅田 大，石井 陽一郎，高橋 邦彦，萱谷 太 \\ 大阪母子医療センター小児循環器科
}

\section{Status and Issues of Pediatric Palliative Care for Patients with Chronic Heart Failure in Our Hospital}

\author{
Masayoshi Mori, Hisaaki Aoki, Takuya Fujisaki, Kazuhisa Hashimoto, Kumiyo Matsuo, \\ Dai Asada, Yoichiro Ishii, Kunihiko Takahashi, and Futoshi Kayatani \\ Department of Pediatric Cardiology, Osaka Women's and Children's Hospital, Osaka, Japan
}

Background: With the improved outcomes of congenital heart diseases, the number of patients dying from heart failure in adulthood is increasing. Palliative care for chronic heart failure is becoming increasingly important, but only few studies have reported on pediatric palliative care for patients with heart failure.

Methods: Pediatric cardiac patients aged $>10$ years who died between 2000 and 2020 were included. The characteristics of the patients who died from heart failure, including their clinical symptoms, medications, ventilators, multi-professional conferences, informed consent, psychologist intervention, and chest compressions, were studied retrospectively.

Results: Seven patients died from heart failure, which was the most common cause of death. The median age at the time of death from heart failure was 15 years (range, 10-24 years). Multi-professional palliative conferences were held for two cases (29\%), and informed consent was provided for one case. Sedation drugs were used in five patients $(71 \%)$, but opioids were not used in any of the cases except for the orally intubated patients. Dyspnea was present in almost all the patients.

Conclusion: Palliative care for patients with pediatric heart failure is still developing, and a multi-professional palliative care team and system must be established.

Keywords: palliative care, pediatric, heart failure, end of life, congenital

背景 : 先天性心疾患は, 成人期に心不全で死亡する患者が増加している. 慢性心不全の緩和ケアが重 要視されてきているが，若年での心不全緩和ケアの報告は少ない.

方法：2000 年から 2020 年に当院で死亡した 10 歳以上の小児心疾患患者のうち心不全死の 7 症例を対 象とした. 心不全死の頻度, 患者の背景, 終末期症状, 各薬物使用状況, 人工呼吸器の使用, 多職種 カンファレンス, 本人告知, 心理士介入について後方視的に検討した.

結果 : 心不全での死亡時年齢は中央值 15 歳（10２4 歳). 多職種カンファレンスは 2 例 $(29 \%)$, 本 人告知は 1 例であった。鎮静薬は 5 例 $(71 \%)$ で使用されていたが, 経口挿管患者以外のオピオイド 使用は $0 \%$ であた。呼吸困難はほぼ全例で認めた。

結論：心不全のコントロールだけでなく, 疼痛や精神的な症状に対する緩和ケアを行うために, 多職 種連携を行った緩和医療体制の確立が必要である.

2021 年 2 月 15 日受付, 2021 年 4 月 26 日受理

著者連絡先：テ594-1101 大阪府和泉市室堂町 840 大阪母子医療センター小坚循環器科＼cjkstart森＼cjkstart雅啓

doi: 10.9794/jspccs.37.208

(C) 2021 Japanese Society of Pediatric Cardiology and Cardiac Surgery 


\section{背 景}

緩和ケア（palliative care）は, World Health Organization（WHO）で提唱された「生命を脅かす疾患 に対して, 痛みやその他の身体的・ 心理社会的・スピ リチュアルな問題を早期に抽出・評価し, 苦痛を予防 し和らげることで, 患者とその家族の Quality Of Life （QOL）を向上させるアプローチ方法」である ${ }^{1)}$. 緩 和ケアは多職種チームによってなされ, 死別後の家 族の精神的苦痛もケアの対象とすることを特徵とす る. 本邦の緩和ケアは 2006 年にがん対策基本法が定 められたことにより, がん患者を中心に発展してき $た^{2)}$. しかし近年, 慢性心不全による死亡患者数が増 加し続けており, 慢性心不全患者への緩和ケアの重 要性が再認識されている ${ }^{3)}$. 先天性心疾患患者におい ても, 年々成人到達例が増加して抢り ${ }^{4)}, 2015$ 年に ドイツから発表された全国データベースでは ${ }^{5)}$, 成 人先天性心疾患に打ける死亡原因は 2009 年以前まで は Sudden Cardiac Death が最多であったが, 2009 年 以降は心不全死が最も多い死因となっている. 心不 全緩和ケアの体制として 2010 年に日本循環器学会か ら「循環器疾患における末期医療に関する提言」が上 梓され 6), 保険診療においても 2018 年 4 月から慢性 心不全患者に関しても緩和ケア診療加算が算定可能と なった. しかし，小児心不全に対する緩和ケアについ ては, 明確なガイドラインや指針はなく本邦からの報 告も認めない. 今回は, 当院における思春期・成人期 に心不全で死亡した患者の緩和ケアの現状と今後の課 題について検討した.

\section{方 法}

2000 年 1 月から 2020 年 12 月までの 21 年間, 大 阪母子医療センターでフォローアップされており, 10 歳を超えて死亡した 21 症例（Fig. 1) のうち慢性 心不全で死亡した 7 症例を対象とした。 心不全が死亡 原因であった患者の死亡時期, 死亡年齢, 診断名, 性 別, 染色体/遺伝子疾患の有無, 最終手術, New York Heart Association Functional Classification (NYHA) 分類, 死亡場所, 1 年間の入院回数, 最終入院期間, 心不全末期での臨床症状, 鎮静薬/オピオイドの使 用, カテコラミンの使用, 利尿剂の使用, 多職種 (医 師と看護師以外の職種）で実施された緩和医療カン ファレンスの有無, 本人への終末期である病状の告知 有無 (informed consent), 心理士介入の有無, 胸骨 圧迫の有無, 人工呼吸器の使用有無について, 診療録

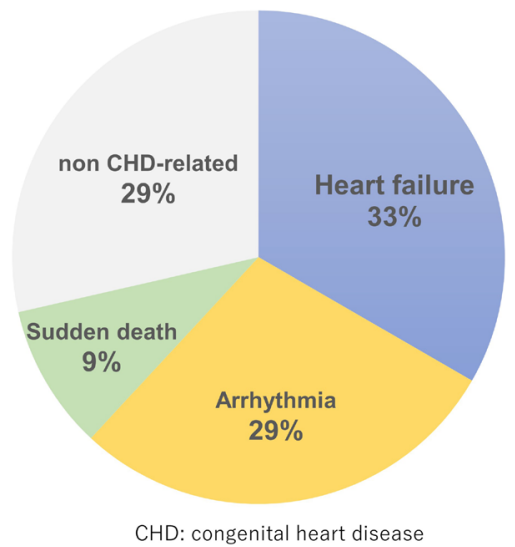

Fig. 1 Causes of death

を用いて後方視的に検討した. 本研究は大阪母子医療 センター倫理委員会の承認を得ている（倫理委員会承 認番号：1414).

\section{結 果}

心不全で死亡した対象となる 7 例（女性 2 人）の 患者概要を Table 1 に示す。死亡時の年齢は中央值 15 歳（10〜24 歳）であった. 心疾患は, 心筋症が 2 例, 単心室症例が 3 例, 二心室症例が 2 例であった. 染色体/遺伝子疾患が確認された症例は 3 例認めた. NYHA 分類は IV が最も多く, 5 例 (71\%) であっ た. NYHA 分類が III であった Case 2 は大動脈弁狭 窄による虚血性心不全死であり, 経過が比較的急激で あった。死亡場所は集中治療室が 1 例 (14\%), 循環 器病棟が 6 例 $(86 \%)$ であった。年間の入院回数は 中央值 2 回 (1 7 回), 最終入院期間の中央值は 36 日（11〜114 日）であった。コントロール困難であっ た病状末期時の臨床症状を Fig. 2 に示す. 多呼吸は 7 例 (100\%) に伴い, NYHA 分類が IV の症例では, 全例で起坐呼吸を認めた，浮腫は 6 例 $(86 \%)$, 倦急 感は 7 例 (100\%) で認めた。疼痛は 5 例（71\%）で あり, 前胸部や背部痛などがありロキソプロフェン で対応を行っていた。食欲不振は 6 例 $(86 \%)$, 掻痒 感は 3 例（43\%）であった。不眠は 5 例（71\%）で あった。公不全患者の薬物治療と多職種の関わりの内 訳を Table 2 に示す．心不全そのものに対する治療と して人工呼吸器を装着した症例は 3 例 $(43 \%)$ で, うち 1 例は気管切開が既に施行されていた. 薬物治 療は, 鎮痛/鎮静薬の使用を行った症例は 5 例（71\%） であった. 鎮静薬については, midazolam（ミダゾラ $\left.ム^{\circledR}\right)$, triclofos sodium (トリクロリールシロップ®), hydroxyzine pamoate（アタラックス-P 注射液 ${ }^{\circledR}$ ) が 


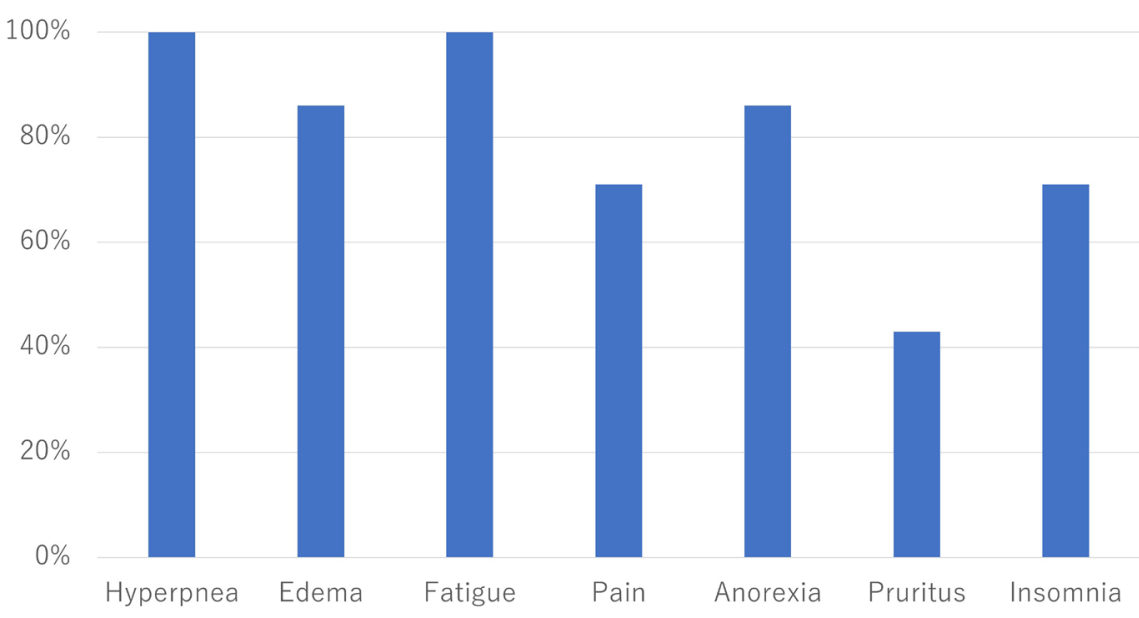

Fig. 2 Symptoms of chronic heart failure patients at end-stage

Table 1 Characteristics of chronic heart failure patients

\begin{tabular}{|c|c|c|c|c|c|c|c|c|c|}
\hline No & $\begin{array}{c}\text { Year of } \\
\text { death }\end{array}$ & $\begin{array}{l}\text { Age } \\
\text { (year) }\end{array}$ & Diagnosis & Genetic disorder & Operation & NYHA & $\begin{array}{c}\text { Location of } \\
\text { death }\end{array}$ & $\begin{array}{c}\text { Number of } \\
\text { hospitalization } \\
\text { (/year) }\end{array}$ & $\begin{array}{l}\text { Length of last } \\
\text { hospitalization } \\
\text { (days) }\end{array}$ \\
\hline 1 & 2001 & 21 & ToF/MAPCA & - & - & IV & C-ward & 1 & 47 \\
\hline 2 & 2004 & 16 & DCM & - & - & IV & C-ward & 3 & 36 \\
\hline 3 & 2007 & 12 & DORV & $22 q 11.2$ deletion & $\mathrm{PAB}, \mathrm{BDG}$ & III & PICU & 2 & 114 \\
\hline 4 & 2007 & 10 & $\mathrm{DCM}$ & Becker dystrophy & - & IV & C-ward & 2 & 40 \\
\hline 5 & 2016 & 24 & DORV, MS, PA & - & BDG & IV & C-ward & 7 & 36 \\
\hline 6 & 2018 & 10 & vAS & Myhre syndrome & - & III & C-ward & 1 & 11 \\
\hline 7 & 2019 & 15 & Left iso, SRV & - & $\begin{array}{c}\text { BDG } \\
\text { EC-TCPC }\end{array}$ & IV & C-ward & 2 & 35 \\
\hline
\end{tabular}

BDG, bidirectional Glenn; C-ward, cardiac-ward; DCM, dilated cardiomyopathy; DORV, double outlet right ventricle; EC-TCPC, extracardiac total cavopulmonary connection; Left iso, left isomerism; MAPCA, major aortopulmonary collateral arteries; MS, mitral valve stenosis; PA, pulmonary atresia; PAB, pulmonary artery banding; PICU, pediatric intensive care unit; SRV, single right ventricle; ToF, tetralogy of Fallot; vAS, aortic valve stenosis.

Table 2 Palliative care and medical therapy of chronic heart failure patients

\begin{tabular}{|c|c|c|c|c|c|c|c|c|c|}
\hline \multirow{2}{*}{ No } & \multirow{2}{*}{$\begin{array}{c}\text { Multi } \\
\text { occupational } \\
\text { discussion }\end{array}$} & \multirow{2}{*}{ IC } & \multirow{2}{*}{ Clin Psychol } & \multirow{2}{*}{ CPR } & \multirow{2}{*}{ Respirator } & \multicolumn{4}{|c|}{ Drug } \\
\hline & & & & & & Sedation & Opioid & CA & Diuretics \\
\hline 1 & - & - & - & - & - & + & - & + & + \\
\hline 2 & - & - & - & - & - & - & - & + & + \\
\hline 3 & - & - & - & + & + & + & + & + & + \\
\hline 4 & - & - & - & - & + & + & + & + & + \\
\hline 5 & + & + & + & - & - & + & - & + & + \\
\hline 6 & - & - & - & + & - & - & - & - & + \\
\hline \multirow[t]{2}{*}{7} & + & - & + & - & + & + & - & + & + \\
\hline & $2 / 7(29 \%)$ & $1 / 7(14 \%)$ & $2 / 7(29 \%)$ & $2 / 7(29 \%)$ & $3 / 7(43 \%)$ & $5 / 7(71 \%)$ & $2 / 7(29 \%)$ & $6 / 7(86 \%)$ & $7 / 7(100 \%)$ \\
\hline
\end{tabular}

CA, catecholamine; Clin Psychol, clinical psychologist; CPR, cardio pulmonary resuscitation; IC, informed consent.

使用されていた。オピオイドの使用症例は経口挿管管 理を行った2例 (29\%) のみで fentanyl が使用され ていた. morphineの使用症例は認めなかった. オピ オイドの使用について議論をされた症例は 1 例存在
した. 薬剤投与については，カテコラミン使用 6 例 (86\%), 利尿剂使用 7 例 (100\%) で実施されており, 抗アレルギー以外の睡眠薬投与は 1 例 $(14 \%)$ のみ であった. カテコラミンは虚血性心不全で死亡した大 
動脈弁狭窄の 1 症例を除き全例で使用されていた。緩 和医療カンファレンスを行った症例は，2例（29\%） あり, 実施時期は各々死亡する 10 日前, 12 日前で心 不全終末期のタイミングであった. 2016 年以降で, 医師・看護師以外の職種での緩和カンファレンスが 開かれていた. 本人への病状告知については 24 歳の 1 例（14\%）の及実施された。本人へ病状説明が行わ れなかった理由としては, 低年齢であるためや, ご両 親の意向や意識障害があることがあげられていたが, 診療録に記載されていない症例もあり定かではなかっ た。 心理士介入は 2 例 (29\%), 胸骨圧迫は2例 (29\%) で実施された. 胸骨圧迫を行った理由については 2 例 ともご両親の希望であった. 1 例は虚血性心不全で死 亡した大動脈弁狭窄の症例で, 比較的急峻な経過をた どった症例であった. もう 1 例はご両親の強い意向が あり, 胸骨圧迫が複数回実施されていた。

\section{考察}

今回の結果では, 当院での先天性心疾患における 10 歳以上での心不全症例に対しては, 利尿剂やカテ コラミン投与など心不全コントロールにつながる薬剤 投与はほぼ全例で実施されていたが，身体的緩和ケア として非経口挿管患者で持続鎮静・鎮痛を行った症例 は $1 / 5$ 例 (20\%) と少なく, 心不全に対する緩和ケア の多職種カンファレンスを行ったものも2例（29\%） と少なかった. 特に, 本人への病状告知を行った症例 は 1 例（14\%）と少ない結果であった. 心不全緩和 ケアの特徵と実施時期, 心不全緩和ケアチーム, 心不 全緩和ケアの評価方法, 小览患者への病状告知の問題 点, ACPについて以下に考察する.

\section{慢性心不全緩和ケアの特徵}

慢性心不全はがんと異なり, 比較的ゆるやかに身体 機能が低下する一方で, 急速に病態が変化することが あるため, 予後予測が難しい. 予後予測の困難が, 慢 性心不全の緩和ケアの導入時期や治療の中断や差し 控えの時期決定が難しい原因となっている ${ }^{7)}$. 慢性心 不全の緩和医療はがん緩和医療と異なり, 治療が最 後まで継続されることで苦痛の緩和にもつながるた め, 一般的には最後まで治療が継続される ${ }^{7)}$. 心不全 患者の呼吸困難や苦痛を取り除くためには, オピオイ ドの使用が有用である ${ }^{8)}$. 2018 年に本邦から出され た成人慢性心不全緩和ケアの報告 ${ }^{9)}$ では, 慢性心不 全の終末期では苦痛緩和のため $87 \%$ の患者にモルヒ ネの投与が実施されていた。 小児の緩和ケアについて
はがんや神経疾患の患者が対象とされることが多く, 心不全の緩和ケアはあまり実施されていない現状があ る ${ }^{10)}$. 今回の検討においても, 非挿管患者の才ピオ イドの使用は 0 件であった．オピオイドの使用につい て議論をされた症例は 1 例存在したが，心不全終末期 にオピオイドを使用することは一般的でないという認 識と，呼吸抑制や血圧低下のデメリットを考え使用は 行われていなかった. Lee らの報告では ${ }^{11)}$ ，小児心 疾患で死亡した患者 $(\mathrm{n}=136)$ において, 緩和ケア についての議論は死亡するまでに $54 \%$ の患者しか行 われておらず, 議論の開始時期も死亡 1 週間以内に初 めて行われていたものが 57\%であった。 また終末期 の鎮静薬についても56\%の使用に留まっていた. こ れらの原因としては, 小児循環器に携わる医療スタッ フが緩和医療への移行に慣れていないこと，また積極 的治療を最後まで希望されるご両親の意向が背景にあ ることが影響していると述べている. 自施設において も，心不全のコントロールにつながるものはできてい たが，精神的な症状に対する緩和ケアやオピオイドの 使用，本人の告知状況などが不十分であった。 心不全 緩和ケアチームの体制を作り，身体的苦痛の評価と緩 和を積極的に行っていくとともに，緩和ケア治療が必 要な心不全症例を抽出し議論していくことが重要であ る.

\section{心不全緩和ヶアの実施時期について}

慢性心不全緩和ケアの導入時期については，以前は 心不全の増悪・緩解を繰り返す循環器末期状態 (endstage）からの開始が推奨されていた ${ }^{6)}$. しかし 2017 年に日本循環器学会から上梓された「急性・慢性心不 全診療ガイドライン」では, 緩和ケアは心不全が症 候性となった段階（心不全ステージ分類 C) から開始 し，より早期に導入すべきと推奨している. 緩和ケア （palliative care）と終末期ケア（terminal care）は同 義ではないことも明記された ${ }^{12,13)}$. また慢性心不全 患者の緩和ケアを行う場合は, 診療加算が可能となっ た. 心不全に対して適切な治療が実施されているにも かかわらず，頻回又は持続的に点滴薬物療法を必要と する状態や, 年 2 回以上の急変時の心不全入院が必 要である場合, 医学的に終末期だと判断される場合が 加算対象となっている. しかし実際は, 診療加算を根 拠に緩和ケアを始めるのではなく, ガイドラインなど を参考に本人の心不全症状が出現しているタイミング で，適切な心不全治療が実施されているかを振り返る とともに, 適切な緩和ケアが実施されているかも同時 に議論すべきであると考える. 


\section{心不全緩和チームについて}

緩和ケアは, 身体的苦痛, 精神的苦痛, スピリチュ アルペイン, 社会的苦痛を早期に評価し, QOL を改 善するアプローチ方法であるが, 多職種の視点で議論 が行われる必要があり, 医師, 看護師, 薬剤師, 臨床 心理士, 理学療法士, 管理栄養士, 医療ソーシャル ワーカー, 臨床工学技士などの緩和ケアチームで構成 される. 日本ホスピス緩和ケア協会が, 厚生労働省の 基準を満たした緩和チームが存在する施設を公表して いるが， 2020 年 11 月の時点では 4 施設の子ども病院 で認定されている ${ }^{14)}$. 諸外国では小坚慢性心不全の 緩和ケアについては, 循環器内科医が院内の緩和ケア 専門医にコンサルトを行い実施されているようであ る ${ }^{15)}$. 当院では血液腫瘍科と精神科を主体とした独 自の緩和ケアチームが存在するが，心不全患者に対し て緩和ケアカンファレンスは定例化して行っていな かった．慢性心不全の緩和チームでは，(1)循環器を専 門とし緩和ケアに造詣が深い医師，(2)緩和ケアを専門 とする医師，(3)精神科を専門とし緩和ケアに造詣が深 い医師の 3 人が揃つていることが理想的とされるが, 少なくとも緩和ケア専門医へ相談できる環境調整が大 切となる ${ }^{16)}$. 当院においては, 2021 年からは小巟循 環器科医が，既に設立されている院内緩和チームに参 加し連携をとることで，心不全患者に対しても緩和力 ンファレンスが必要な症例を抽出し, 多職種緩和カン ファレンスを定例化し行っている. 死別後の家族ケア についても，現在は有志での病棟看護師が独自に手紙 連絡や電話連絡を行っていたが，実施状況については 記載がなく把握ができていなかった．死別後の家族ケ アも系統立てて実施するとともに，当院医療スタッフ を対象に院内での心不全緩和ケア勉強会を行っていく 予定である.

\section{緩和ケアの評価について}

緩和ケアを評価する代表的ツールとして，STAS (Support Team Assessment Schedule) や IPOS (Integrated Palliative care Outcome Scale) などがある. STAS は，1986 年にイギリスで開発された，患者・ 家族への緩和ケアの成果を評価するッールであり, STAS-Japan として日本語版が存在する．主要ケアス タッフが，身体症状や患者の精神状況，ご家族の不安 や病識などを 9 項目で評価し，チームケアが機能的 に活動できているかを確認するツールである. IPOS はSTAS と異なり，評価者が医療者だけでなく患者自 身による自己評価も可能であり，慢性心不全の患者 評価にも有用である ${ }^{17,18)}$. STAS や IPOS は全世界で
用いられており，評価をスコアリングすることで，緩 和ケアの基本的なアセスメント教育にもなり，緩和 ケアを振り返ることでより質の高いケアへ繋がると される ${ }^{19,20)}$. STAS や IPOS は特定の疾患をターゲッ トにしない緩和ケアの包括的尺度であるが，慢性心 不全患者に用いるために開発された質問表も存在す る. Minnesota Living with Heart Failure Questionnaire ${ }^{21)}$, Quality of Life in Severe Heart Failure Questionnaire ${ }^{22)}$ などが慢性心不全患者に対する代表的な質 問ツールであり，心肺運動負荷試験により運動生理学 的指標との関連をみることで妥当性を評価している. しかしこれらは項目数が多く包括的尺度と併用する場 合には回答する患者の負担が大きいことが問題とな る ${ }^{23)}$ ．小览心不全の緩和ケアを実施する上で，QOL のスコアリング評価を取り入れたほうがよりよい判断 が可能になると思われるが，どの評価尺度を用いるか は議論の余地がある.

\section{小児心疾患患者への病状告知と Advance Care Plan- ning (ACP)}

文部科学省・厚生労働省が制定した「人を対象と する医学系研究に関する倫理指針」では，未成年者 であっても，中学校等の課程を修了している又は 16 歳以上の未成年者で十分な判断能力を有すると判断 される場合は，代諾者ではなく当該研究対象者から Informed consent を得ることが求められている ${ }^{24)}$. 一方 ACP は，年齢や病期にかかわらず，患者の価值 観や人生の目標, 医療に関する希望を理解し, 患者・ 家族と医療従事者が共有できるよう自発的に話し合う プロセスを指す ${ }^{25)}$ ．小児における ACP の問題点とし て，自分で意思決定できない幼少時は代理意思決定者 である両親との話し合いが中心となることである。ご 家族が非現実的な期待をもっている場合や医療者が十 分な ACP のトレーニングを受けていないことなども 障壁になりえるとされる ${ }^{26)}$ ．思春期年齢の場合にお いても，重症である予後を思春期に告知することが， 本人の生きる希望を失ってしまうことに繋がるのでは ないかという医療者側の不安もあり, 本人への病状告 知や ACP が実施されにくいという現状がある ${ }^{27)}$ 。米 国の国立がんセンターにおいて ${ }^{28)}$ ，思春期から若年 成人（16〜28 歳）のがん患者を対象に ACP を希望す るかどうかアンケート調査を行った報告があり，結 果，96\%の患者が ACP を希望していた。一方，思春 期がんに対する ACP は，内科医と比べて小児科医の $\mathrm{ACP}$ 実施率は低いとされており，小览科医は ACP に 慣れていないことが要因とされている ${ }^{29)}$. ACP を実 
施することで，患者本人だけでなく，重大な選択を迫 られたご両親のストレス，不安，抑うつも軽減される ほか，医療従事者の道徳的苦痛も軽減することが知ら れており，より患者本人とご家族の視点に立った緩和 ケアや終末期ケアを提供することが可能となるため, 適正なタイミングで行われた ACP は非常に有用であ $3^{30,31)}$. Els Troost $5^{32)}$ は, 先天性心疾患患者に対

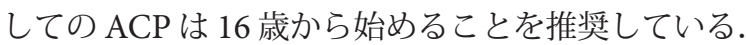
今回の検討では，保護者と本人への病状告知について 議論したものは 2 例（29\%）であり，これは既知の 報告と比べて同程度に少なかった ${ }^{11)}$ 。また検討時期 については各々死亡する 14 日以内と終末期に近い状 態であった. 本人への病状説明を検討したが実施さ れなかった 1 例については，年齢が 15 歳であること もあり，ご家族の希望もあり実施しなかった。本人に 実際に病状説明を行った症例は 24 歳の 1 例のみであ り，ご家族に確認した後に本人へ病状説明を行った。 持続鎮静についてはご両親の抵抗感があり，希望され なかったため実施されていなかった。本人への病状 説明後に本人から持続鎮静の希望があり, midazolam の持続投与を開始した。本人の苦痛軽減につながっ たが，少なくとも終末期よりも早期での ACP が重要 と考えられた。本人へ死が近いことを伝える説明や ACP の適正なタイミングについては一定の見解はな いが，患者本人が 16 歳以上となり十分な判断能力を 有していると考えられる場合，もしくは慢性心不全が 進行していると判断した時点では少なくとも，終末期 に入る前に本人への説明内容をどうするか ACP 実施 タイミングについてどうするかを多職種チームで議論 を行っておくべきだと考える。ご両親に説明を行い意 向確認し，ご両親に対してのケアを行うことも非常に 重要であるが，実際に苦しんでいるのは患者本人であ ることも忘れず，患者自身の希望も十分くみ取れるよ うにアプローチを行う必要がある.

\section{本研究の限界と今後の課題}

本研究は単施設でのカルテ記載を用いた後方視的研 究であり, カルテ記載以外の症状や病状告知について の情報が十分に描出できていない可能性がある. 今後 は, 病状と緩和ケアの進行状況をテンプレートでカル テ記載を行い情報漏れがないように緩和ケア記録を行 う予定である。

\section{結 語}

当院での小児心不全の緩和ケアは，心不全のコント
ロールにつながる治療はできていたが，疼痛や精神的 な症状に対する緩和ケアや，オピオイドの使用，本人 の告知状況や ACP は不十分であった。 今後は身体的 苦痛の評価と緩和を積極的に行い，心不全緩和ケア チームの体制を作り，緩和ケア治療が必要な症例を抽 出し議論していくことが重要と考える.

\section{利益相反}

全ての著者は日本小児循環器学会の定める利益相反に関する開 示事項はない.

\section{著者の役割}

森雅啓は筆頭著者として論文を執筆した。青木寿明は論文執筆 に抢ける直接的な指導を行った，藤崎拓也，橋本和久，松尾久 実代，浅田大，石井陽一郎，高橋邦彦，荁谷太は論文の重要な 知的内容に関わる批判的校閲に関与した。

\section{引用文献}

1) World Health Organization : https://www.who.int/ health-topics/palliative-care (2021/1/1 閱覧)

2）中澤葉宇子：1. わが国の緩和ケアの制度と看護 A. 国 の制度と看護. ホスピス・緩和ケア白書 2019, pp2-6

3) Kavalieratos D, Gelfman LP, Tycon LE, et al: Palliative care in heart failure: Rationale, evidence, and future priorities. J Am Coll Cardiol 2017; 70: 1919-1930

4) Shiina Y, Toyoda T, Kawasoe Y, et al: Prevalence of adult patients with congenital heart disease in Japan. Int J Cardiol 2011; 146: 13-16

5) Engelings CC, Helm CP, Abdul-Khaliq H, et al: Cause of death in adults with congenital heart disease: An analysis of the German National Register for Congenital Heart Defects. Int J Cardiol 2016; 211: 31-36

6）循環器疾患における末期医療に関する提言（JCS 2010）： https://www.j-circ.or.jp/old/guideline/pdf/JCS2010_nonogi_h.pdf (2021/1/1 閲覧)

7）宮下光令, 柴 信行, 下川宏明：末期心不全の緩和ケア を考える. 心臟 2012; 2: 501-511

8) Ponikowski P, Voors AA, Anker DS, et al: ESC Scientific Document Group: 2016 ESC Guidelines for the diagnosis and treatment of acute and chronic heart failure. Eur Heart J 2016; 37: 2129-2200

9) Kuragaichi T, Kurozumi Y, Ohishi S, et al: Nationwide survey of palliative care for patients with heart failure in Japan. Circ J 2018; 82: 1336-1343

10) Feudtner C, Kang IT, Hexem RK, et al: Pediatric palliative care patients: A prospective multicenter cohort study. Pediatrics 2011; 127: 1094-1101

11) Lee J, Kim BG, Song KM, et al: End-of-life care of hospitalized children with advanced heart disease. J Korean Med Sci 2020; 35: 107

12) Guidelines for Diagnosis and Treatment of Acute and Chronic Heart Failure (JCS 2017/JHFS 2017) : https:// www.j-circ.or.jp/old/guideline/pdf/JCS2017_tsutsui_ h.pdf (2021/1/1 閲覧) 
13) Allen AL, Stevenson WL, Grady LK, et al: American Heart Association; Council on Quality of Care and Outcomes Research; Council on Cardiovascular Nursing; Council on Clinical Cardiology; Council on Cardiovascular Radiology and Intervention; Council on Cardiovascular Surgery and Anesthesia: Decision making in advanced heart failure: A scientific statement from the American Heart Association. Circulation 2012; 125: 1928-1952

14）日本ホスピス緩和ケア協会：緩和ケア病棟入院料届け出 施設一覧 $(2020 / 11 / 15)$ https://www.hpcj.org/what/pcu_ list.pdf (2021/1/1 閲覧)

15) Morell E, Wolfe J, Scheurer M, et al: Patterns of care at end of life in children with advanced heart disease. Arch Pediatr Adolesc Med 2012; 166: 745-748

16）柴田龍宏：心不全緩和ケアチームの作り方. 心臓 2019; 51: 133-138

17）患者・医療者による緩和ケアの質の評価 Integrated Palliative care Outcome Scale Ver0.51. http://plaza.umin. ac.jp/pos/IPOS_manual_ver0.51.pdf (2021/1/1 閲覧)

18) Roch C, Palzer J, Zetzl T, et al: Utility of the integrated palliative care outcome scale (IPOS): A cross-sectional study in hospitalised patients with heart failure. Eur J Cardiovasc Nurs 2020; 19: 702-710

19）宮城千秋, 神里みどり：緩和ケア病棟における緩和ケア の質評価ツールーSTAS-J 導入に対するコア看護師の認 識一. 沖縄県立看護大学紀要 $2011 ; 12: 65-72$

20) Collins SE, Witt J, Bausewein C, et al: A systematic review of the use of the palliative care outcome scale and the support team assessment schedule in palliative care. J Pain Symptom Manage 2015; 50: 842-853

21) Rector TS, Kubo SH, Cohn JN: Patient's self-assessment of their congestive heart failure: Content, reliability, and validity of a new measure, the Minnesota Living with Heart Failure questionnaire. Heart Fail 1987; 3: 198-209

22) Wiklund I, Lindvall K, Swedberg K, et al: Self assessment of quality of life in severe heart failure: Aninstrument for clinical use. Scand J Psychol 1987; 28: 220-225

23) Tamura $M$, Omiya $K$, Yamada $S$, et al: Development of measure for disease-specific quality of life in patients with chronic heart failure. J Cardiol 2003; 42: 155-164

24）厚生労働省：人を対象とする医学系研究に関する倫理指 針（平成 29 年 2 月 28 日一部改正）https://www.mhlw. go.jp/file/06-Seisakujouhou-12600000-Seisakutoukatsu kan/0000168764.pdf (2021/1/1 閲覧)

25) Sudore LR, Lum DH, You JJ, et al: Defining advance care planning for adults: A consensus definition from a multidisciplinary delphi panel. J Pain Symptom Manage 2017; 53: $821-832$

26）余谷暢之，木澤義之：2. 小児緩和ケアの現状と展望 H. 研究の動向. ホスピス・緩和ケア白書 2017 年度版, pp34-37

27) Yotani N, Kizawa Y, Shintaku H: Differences between pediatricians and internists in advance care planning for adolescents with cancer. J Pediatr 2017; 182: 356-362

28) Wiener $\mathrm{L}$, Zadeh $\mathrm{S}$, Battles $\mathrm{H}$, et al: Allowing adolescents and young adults to plan their end-of-life care. Pediatrics 2012; 130: 897-905

29) Hughes B, O'Brien RM, Flynn A, et al: The engagement of young people in their own advance care planning process: A systematic narrative synthesis. Palliat Med 2018; 32: 1147-1166

30) Detering MK, Hancock DA, Reade CM, et al: The impact of advance care planning on end of life care in elderly patients: Randomised controlled trial. BMJ 2010; 340 mar23 1: 1345

31) Elpern HE, Covert B, Kleinpell R: Moral distress of staff nurses in a medical intensive care unit. Am J Crit Care 2005; 14: 523-530

32) Troost E, Roggen L, Goossens E, et al: Advanced care planning in adult congenital heart disease: Transitioning from repair to palliation and end-of-life care. Int J Cardiol 2019; 279: 57-61 